\title{
Microsatellite polymorphism and genetic impact of restocking in Mediterranean brown trout (Salmo trutta L.)
}

\author{
C. POTEAUX*, F. BONHOMME \& P. BERREBI \\ Laboratoire Génome et Populations, CNRS-UPR 9060, Université Montpellier II, Cc63, Place Eugène Bataillon, \\ 34095 Montpellier Cedex 05, France
}

\begin{abstract}
The genetic impact of restocking Mediterranean brown trout populations with hatchery stocks was investigated in the Orb River drainage (France), using genetic data from three microsatellite loci. We sampled two wild populations, the main river which is restocked each year and one of its tributaries which has not been restocked for 6 years. Each sample was divided into two age groups (juveniles/ adults). Introgression of each native population by hatchery stocks was previously estimated using allele frequencies from two diagnostic protein-coding loci and one mtDNA haplotype. The genetic structure and allelic frequency at three microsatellite loci in native populations were compared with two hatchery samples belonging to stocks usually used for restocking this drainage. High levels of polymorphism (23-27 alleles per locus) were detected for two loci, whereas the third was less polymorphic. Polymorphism was significantly higher in the restocked population than in the now undisturbed population. Significant differences between age groups were observed in the main river, but not in its tributary. The introgression estimates using microsatellites were compared to those obtained from proteins and mtDNA. The different possible origins of alleles common to hatcheries and wild populations (homoplasy, ancestral polymorphism or introgression) are discussed.
\end{abstract}

Keywords: brown trout, introgression, microsatellite, polymorphism, restocking, Salmo trutta.

\section{Introduction}

Conservation of genetic diversity in natural fish populations has long been a challenge (several articles in STOCS, 1981), particularly since the impact of nonnative species introductions has been noticed. Among the questions opened by these introductions is the impact of restocking on the genetic integrity of aboriginal populations. For fish, non-native hatcheryreared individuals are stocked abundantly in rivers for recreational purposes. One long-term effect of these practices could result in the loss of genetic originality of wild populations, by introgression with hatcheryborn fish (Hindar et al., 1991).

Different types of genetic markers have been developed to study the interactions of domesticated and native fish. The genetic impacts of restocking on natural populations have been documented with some precision using data from diagnostic enzyme loci in the brown trout, Salmo

*Correspondence and present address: Laboratoire d'Ethologie Expérimentale et Comparée, Université Paris XIII, 93430 Villetaneuse Cedex, France. E-mail: chantal.poteaux@leec.univ-paris13.fr trutta (Guyomard, 1989; Garcia-Marin et al., 1991). In this taxon, two diagnostic loci allow sorting of the geographical forms identified in France (Krieg \& Guyomard, 1985): the southern form found in Mediterranean watersheds, and the Atlantic form found elsewhere and to which most hatchery stocks belong. There is evidence of introgression into the gene pool of wild Mediterranean trout populations in several river drainages (BarbatLeterrier et al., 1989; Poteaux \& Berrebi, 1997). These studies have usually showed that despite the intense restocking practices, the genetic impact of introductions remains rather low.

The origin of hatchery stocks and their introgressive impact on native populations of brown trout can easily be assessed only in the Mediterranean basin, with two diagnostic protein-coding loci and one mtDNA haplotype (Bernatchez et al., 1992), but these genetic markers are too few for a precise estimation. In addition, there is evidence that enzyme loci may be subjected to selective pressures (Poteaux et al., 1998b) likely to modify their introgressive behaviour. Moreover, the polymorphism level available with protein-coding loci may be a limiting factor for the estimation of effective size, a parameter 
linked to heterozygosity and mutation rate (Crow \& Kimura, 1970), and important in assessing the effect of domestic gene flow. For all these reasons, highly variable markers such as microsatellites, which are supposed to be neutral in most instances, may provide a convenient level of polymorphism.

The degree of divergence of Mediterranean trout from Atlantic domesticated forms is quite high for populations of the same species (Nei's distance $=0.1$ for allozymes). Thus, we expect to find a reasonable number of informative alleles, whatever the level of polymorphism. Microsatellite loci are highly suitable for population studies because they are PCR-detectable, and because alleles differing by $1 \mathrm{bp}$ can be separated on high-resolution gels. Estoup et al. (1993) have isolated a number of microsatellite loci for a biogeographical study of European trout. Indeed, these authors have shown that some microsatellites possess alleles discriminating between the Atlantic and the Mediterranean forms. However, few individuals per locality were analysed, so detailed population structure could not be studied.

This paper represents a more quantitative attempt to study with microsatellite loci the genetic structure of disturbed trout populations, limited in scope to a small river drainage in southern France. Within this drainage we compared the polymorphism and the genetic structure of a sample from the main river, which is annually restocked, with a sample from a tributary for which restocking has not been reported for several years. A previous study of the same samples with protein-coding loci has shown that variability and introgression level were higher for the restocked sample (Poteaux et al., 1998b). Furthermore, the analysis by RFLP of the control region of mtDNA also confirmed that the level of introgression of the restocked population was twice that of the undisturbed population and twice that given by protein-coding loci (Poteaux et al., 1998a). Here, we verify the power of microsatellite loci for measuring population differentiation and their suitability for estimating introgression from domestic strains.

\section{Materials and methods}

\section{Samples}

Four samples of French brown trout were electrofished in October 1993: two populations from the Orb system which drains into the Mediterranean - Orb river $(N=94)$ and Tes river $(N=98)$; and two hatchery stocks that were usually used to restock this drainage La Canourgue, in the Lozère region $(N=50)$ and Brassac, in Tarn $(N=29)$. Details of the populations sampled and the stocking practices are described in Table 1. We compared the populations from the main river (Orb), which is intensively restocked, to its tributary (Tes) where restocking was stopped at the end of 1987. In both natural populations, two ageclasses were determined from both scale-readings and length-frequency distributions: the fry group, designated as cohort $0+$, and all the other fish combined, designated as group $>1++$.

Total genomic DNA was isolated from blood in TNESurea (10 mм Tris- $\mathrm{HCl}, 10 \mathrm{~mm}$ EDTA, 2\% SDS, $0.3 \mathrm{м}$ $\mathrm{NaCl}, 4 \mathrm{~m}$ urea, $\mathrm{pH}=8)$, or from muscle in TE (10 mM Tris- $\mathrm{HCl}, 1 \mathrm{~mm}$ EDTA, $\mathrm{pH}=7.4)$ buffer after overnight incubation at $55^{\circ} \mathrm{C}$ with proteinase $\mathrm{K}(100 \mu \mathrm{g} / \mathrm{mL}$ at final concentration) and extracted by the phenol-chloroform method. Other organs were collected and frozen for allozyme studies.

\section{Microsatellites}

A partial genomic library was constructed from highmolecular weight DNA of domestic trout, according to Garcia de Leon et al. (1995). Recombinant clones of 300-800 bp size were gridded out on duplicate plates and clones containing microsatellites were identified using the library screening procedures described in Garcia de Leon et al. (1995). Positive clones were sequenced using the Sequenase kit (USB). PCR primers were designed to anneal inside the 30-50 bp flanking the microsatellite array, using the program PRIMER,

Table 1 Sample sizes of brown trout for the Orb drainage and the hatcheries

\begin{tabular}{lccccc}
\hline $\begin{array}{l}\text { Origin } \\
\text { of trout }\end{array}$ & River & $\begin{array}{c}\text { Sample } \\
\text { size }\end{array}$ & $\begin{array}{c}\text { Age } \\
\text { group }\end{array}$ & $\begin{array}{c}\text { Restocking } \\
\text { practice }\end{array}$ & $\begin{array}{c}\text { Hatchery origin } \\
\text { of restocking }\end{array}$ \\
\hline Orb & Orb & 94 & $0+=40$ & Intensive† & Brassac + Canourgue \\
Orb & Tes & 98 & $0+=44$ & None & Brassac + Canourgue \\
Hatchery & Brassac & 29 & $>1++=54$ & since 1988 & \\
Hatchery & Canourgue & 50 & & & \\
\hline
\end{tabular}

$\dagger$ See Beaudou (1993) or Poteaux et al. (1998b) for precise details. 
version 0.5 (S. E. Lincoln, M. J. Daly \& E. S. Lander, unpublished).

Two of the 17 microsatellite loci obtained, hereafter designated Strutta-12 and Strutta-58, were chosen for population analysis. The details of the primer sequences for each microsatellite locus and its motif are presented in Table 2. Annealing temperature and $\mathrm{MgCl}_{2}$ concentration were optimized for each locus. PCR reactions $(15 \mu \mathrm{L})$ contained 40-80 ng of total DNA, 0.25 units of Promega Taq polymerase, $140 \mathrm{ng}$ of one unlabelled primer and $140 \mathrm{ng}$ of the other ${ }^{33} \mathrm{P}$ end-labelled primer, $1.5 \mathrm{~mm}$ $\mathrm{MgCl}_{2}, 0.2 \mathrm{~mm}$ of each deoxyribonucleotide, $1 \times$ buffer. The PCR programme consisted of an initial denaturation step $\left(94^{\circ} \mathrm{C}\right.$ for $\left.3 \mathrm{~min}\right)$, followed by 30 cycles of $92^{\circ} \mathrm{C}$ for $45 \mathrm{~s}, 55^{\circ} \mathrm{C}$ for $45 \mathrm{~s}$, and a final extension of $5 \mathrm{~min}$ at $72^{\circ} \mathrm{C}$. A third locus, $M S T-73$, was taken from a previous study (Estoup et al., 1993) and DNA amplifications were performed following their protocol. This locus was chosen because it discriminates between hatchery trout and wild Spanish trout from the Mediterranean basin.

PCR products were mixed with $2 / 3$ volume of formamide loading buffer (Sambrook et al., 1989) and denatured at $95^{\circ} \mathrm{C}$ for $5 \mathrm{~min}$, before electrophoresis in $6 \%$ acryl-bisacrylamide $/ 8 \mathrm{~m}$ urea sequencing gels. The M13-plasmid sequence was used as an external size standard.

\section{Statistical analyses}

Expected heterozygosity values were computed as unbiased estimates (Nei, 1978). All calculations were performed using the computer package GENETIX 3.0 (Belkhir et al., 1996-98). Genetic differentiation was assessed using Wright's F-statistics (Wright, 1951), which were estimated by Weir \& Cockerham's (1984) $f, \theta$ and $F$ for $F_{\mathrm{IS}}, F_{\mathrm{ST}}$ and $F_{\mathrm{IT}}$, respectively. Tests of significance were carried out by permutations. Briefly, 2500 permuted data sets were generated from the original genotype matrix. For $F_{\text {IS }}$, alleles were permuted within samples; for $F_{\mathrm{ST}}$, genotypes (rather than alleles) were permuted among samples. The value of interest (e.g. $F_{\text {IS }}$ ) was calculated for each permuted file, generating a distribution of $F_{\text {IS }}$ values under the null hypothesis. The chance probability of obtaining the original $F_{\text {IS }}$ value under the null hypothesis was estimated as the proportion of the distribution having $F_{\text {IS }}$ values larger than the original value.

Because significant deficits of heterozygotes are frequently caused by null alleles at the microsatellite loci, we estimated the expected allele frequency of a presumed null allele using $x=\left(H_{\mathrm{e}}-H_{\mathrm{o}}\right) /\left(1+H_{\mathrm{e}}\right)$ (Brookfield, 1996), where $x$ represents the estimated frequency of the null allele, and $H_{\mathrm{e}}$ and $H_{\mathrm{o}}$ are the expected and observed frequencies of heterozygotes, respectively.

\section{Introgression}

We analysed the frequencies of hatchery-specific alleles at three microsatellite loci. Because we do not have a pure wild sample at hand, we assumed that all alleles shared between native samples and hatchery stocks were of domestic origin. Although this assumption is not likely to be always true, we propose to use the sum of the frequencies of shared alleles in natural samples as an index of maximal introgression.

In addition, we compared the microsatellite introgression with that reported in a complete analysis of protein polymorphism on the same samples (Poteaux et al., 1998b) and with the introgression estimated from mtDNA data. With allozymes, it is possible to assess precisely the native allele frequencies of wild populations because many Mediterranean populations have been studied in the past (Krieg \& Guyomard, 1985). The frequencies of hatchery-specific alleles at two diagnostic protein-coding loci, $L d h-5$ and $T f$, can then be used to compute the introgression level as proposed in Barbat-Leterrier et al. (1989): $r=\left(f_{\mathrm{s}}-f_{\mathrm{r}}\right) /\left(f_{\mathrm{h}}-f_{\mathrm{r}}\right)$. The proportion of introduced genes $(r)$ is computed as the allele-frequency differences between the sample $\left(f_{\mathrm{s}}\right)$ and the reference population $\left(f_{\mathrm{r}}\right)$, weighted by the allele-

Table 2 Microsatellite characteristics, structures, primer sequences and number of alleles per locus

\begin{tabular}{|c|c|c|c|c|c|}
\hline Locus & $\begin{array}{l}\text { Core } \\
\text { sequence }\end{array}$ & $\operatorname{Primer}\left(5^{\prime}-3^{\prime}\right)$ & $\begin{array}{l}\text { Annealing } \\
\text { temp. }\end{array}$ & $\begin{array}{r}\text { No. of } \\
\text { alleles }\end{array}$ & $\begin{array}{l}\text { Size of the PCR } \\
\text { product (bp) }\end{array}$ \\
\hline$M S T-73$ & $(\mathrm{GT}) 13,(\mathrm{GT}) 3$ & $\begin{array}{l}\text { CTATTCTGCTTGTAACTAGCCTA } \\
\text { CCTGGAGATCCTCCAGCAGGA } \dagger\end{array}$ & $58^{\circ} \mathrm{C}$ & 4 & $137-143$ \\
\hline Strutta-12 & (GT)43 & $\begin{array}{l}\text { AATCTCAAATCGATCAGAAG } \\
\text { AGCTATTTCAGACATCACC } \dagger\end{array}$ & $55^{\circ} \mathrm{C}$ & 27 & $\begin{array}{c}124-206 \\
(25-66 \text { rep.) }\end{array}$ \\
\hline Strutta-58 & (GT)40 & $\begin{array}{l}\text { AACAATGACTTTCTCTGAC } \\
\text { AAGGACTTGAAGGACGAC } \dagger\end{array}$ & $55^{\circ} \mathrm{C}$ & 23 & $\begin{array}{c}101-177 \\
(18-56 \text { rep. })\end{array}$ \\
\hline
\end{tabular}

$\dagger$ Labelled primers.

(C) The Genetical Society of Great Britain, Heredity, 82, 645-653. 
frequency differences between hatchery strain $\left(f_{\mathrm{h}}\right)$ and the reference $\left(f_{\mathrm{r}}\right)$. For the mtDNA, the introgression rate simply corresponds to the frequency of the Atlantic haplotype in wild populations (see Poteaux et al., 1998a for details).

\section{Results}

\section{Cloning and microsatellite analysis}

Twenty-six of the 1450 recombinant clones were identified as positive clones and sequenced. We report here the isolation of 17 microsatellite loci from the brown trout genome (Genbank accession numbers from U60219 to U60230 for 12 of them). We found $12(\mathrm{CA})_{n}$ and one $(\mathrm{CT})_{n}$ microsatellite, with $n$ ranging from 15 to over 75 , two trinucleotide microsatellites, one chimera, and a (CA) microsatellite associated with a 37-bp minisatellite with at least seven repeats. The mean number of repeats observed in our clones is about 32. No (AT) ${ }_{n}$ arrays were found. Thus (CA) motifs appeared to be the most abundant type in the trout genome, consistent with the observations of Estoup et al. (1993) for trout and with other studies on fish (Rico et al., 1993; Garcia de Leon et al., 1995).

Mendelian inheritance of Strutta-12 and Strutta-58 was verified by analysis of genotype ratios in backcross offspring (Poteaux et al. submitted): all frequencies were in agreement with Mendel's expected proportions in the offspring analysed (334 individuals of two backcross experiments).

Average motif number varies from locus to locus and it appears that the longer the array, the greater the polymorphism (Table 2). In all samples combined, MST-73 (15 motifs on average) had only four alleles, Strutta-58 (40 motifs) had 23 alleles and Strutta-12 (37 motifs) 27 alleles.

\section{Hatchery stocks}

Hatchery samples contain no major alleles for Strutta12 and 58, but many alleles at low frequencies $(p<0.1$ in most cases). Some alleles at Strutta-12 and Strutta58 were detected in the hatchery stocks only (Table 3 ). We found only three alleles at locus MST-73, the same as those identified by Presa et al. (1994) in their hatchery samples, but at different frequencies.

The average heterozygosity was high in both cases $(0.77$ for Brassac and 0.84 for La Canourgue). Both hatchery samples show significant departure from HardyWeinberg expectations $(f=0.07, \quad P<0.05$ and $f=0.13, P<0.001)$. Furthermore, domestic stocks significantly differed from each other $(\theta=0.04$, $P<0.001)$.

\section{Wild Mediterranean populations}

The frequency distributions of microsatellite alleles in the Orb and Tes samples show similar patterns: the major alleles correspond to alleles absent from the hatchery stocks (Table 3 ). The predominant allele for $M S T-73$, out of a total of four, corresponds to an allele which seems to be diagnostic between the Mediterranean and domesticated forms (our data; Presa, 1995). For the other two loci, the mean number of alleles per sample is high, 16.5 and 17.5 for Orb and Tes, respectively.

Expected heterozygosity and deviations from HardyWeinberg equilibrium are presented in Table 3: the global $f$ estimation is significant for both samples, but caused by different loci (Strutta-12 for the Orb river and Strutta-58 for the Tes river). Heterozygosity is higher in the Orb sample than in the Tes sample ( 0.74 and 0.59 , respectively) but it is on average lower than the value for the hatchery samples (0.82). Multilocus $f$ are high and significant for both populations $(0.10$ and 0.11 for Tes and Orb, respectively) and for all age groups.

\section{Differentiation between samples and age groups}

The frequency distributions of the different loci show slight differences between the Tes and Orb samples and between age groups $0+$ and $>1++$ (Table 3$)$. On average, these differences are significant between the Orb cohorts $(\theta=0.012, P<0.01)$, but not between the Tes cohorts $(\theta=0)$. The Orb and Tes populations were slightly but significantly differentiated $(\theta=0.02$, $P<0.001)$, this holding true at the level of age groups (between adults $\theta=0.03, P<0.01$ ).

\section{Genetic effect of restocking}

Values of protein-coding and mtDNA introgression indices (Poteaux et al., 1998a) are given in Table 4. Domestic allele frequencies for the protein-coding loci varied from 9 to $38 \%$. They confirmed that both populations were introgressed and the mean introgression index for the Orb population is twice that of its tributary (mean for both loci: $28 \%$ and $12.5 \%$, respectively). That is confirmed by the mtDNA data, for which the introgression level is higher than that of the protein-coding loci.

For the microsatellites, we can distinguish four kinds of alleles in the allelic distribution (Table 3): (i) alleles present only in the hatchery samples, (ii) alleles present only in the Tes and/or Orb samples, (iii) shared alleles that are frequent in the hatchery samples and rare in wild samples and (iv) shared alleles that are rare in the hatchery samples and frequent in the wild samples. 
Table 3 Allele frequencies, expected heterozygosities $\left(H_{\mathrm{e}}\right)$, mean number of alleles $(n)$ and $f$-values for the brown trout samples

\begin{tabular}{|c|c|c|c|c|c|c|c|c|}
\hline \multirow{2}{*}{$\begin{array}{l}\text { Locus, alleles, } \\
H_{\mathrm{e}}, f \text { or } n\end{array}$} & \multicolumn{3}{|c|}{ Tes } & \multicolumn{3}{|c|}{ Orb } & \multirow[b]{2}{*}{ Brassac } & \multirow[b]{2}{*}{ La Canourgue } \\
\hline & $0+$ & $>1++$ & Total & $0+$ & $>1++$ & Total & & \\
\hline \multicolumn{9}{|l|}{$M S T-73$} \\
\hline 137 & 0.035 & 0.019 & 0.026 & 0.038 & 0.13 & 0.095 & 0.034 & 0.34 \\
\hline 139 & 0.849 & 0.88 & 0.866 & 0.744 & 0.611 & 0.647 & - & - \\
\hline 141 & 0.081 & 0.083 & 0.082 & 0.077 & 0.139 & 0.116 & 0.656 & 0.39 \\
\hline 143 & 0.035 & 0.019 & 0.026 & 0.141 & 0.12 & 0.142 & 0.31 & 0.27 \\
\hline$H_{\mathrm{e}}$ & 0.27 & 0.22 & 0.24 & 0.42 & 0.58 & 0.53 & 0.48 & 0.67 \\
\hline$f$ & -0.02 & -0.007 & -0.02 & 0.11 & 0.07 & 0.067 & 0.14 & 0.07 \\
\hline$n$ & 4 & 4 & 4 & 4 & 4 & 4 & 3 & 3 \\
\hline \multicolumn{9}{|l|}{ Strutta-12 } \\
\hline 124 & - & - & - & - & - & - & 0.052 & - \\
\hline 128 & - & - & - & - & 0.01 & 0.006 & 0.103 & - \\
\hline 132 & 0.011 & 0.019 & 0.015 & 0.045 & 0.039 & 0.052 & 0.155 & 0.114 \\
\hline 140 & 0.534 & 0.491 & 0.515 & 0.379 & 0.324 & 0.339 & - & - \\
\hline 142 & 0.011 & - & 0.005 & - & 0.02 & 0.011 & 0.034 & 0.034 \\
\hline 144 & - & - & - & 0.015 & 0.029 & 0.023 & - & 0.045 \\
\hline 146 & 0.011 & 0.009 & 0.01 & 0.03 & 0.029 & 0.023 & - & 0.011 \\
\hline 148 & 0.011 & 0.019 & 0.015 & - & - & - & - & 0.102 \\
\hline 150 & 0.011 & - & 0.005 & 0.015 & - & 0.006 & - & 0.08 \\
\hline 154 & 0.011 & 0.009 & 0.01 & - & 0.01 & 0.006 & - & 0.011 \\
\hline 156 & 0.057 & 0.037 & 0.046 & - & 0.118 & 0.069 & 0.086 & 0.091 \\
\hline 158 & 0.102 & 0.111 & 0.107 & 0.091 & 0.078 & 0.086 & 0.017 & 0.034 \\
\hline 160 & 0.023 & - & 0.01 & 0.061 & 0.029 & 0.046 & 0.069 & 0.114 \\
\hline 162 & 0.159 & 0.259 & 0.209 & 0.061 & 0.216 & 0.149 & 0.017 & - \\
\hline 164 & 0.011 & 0.028 & 0.02 & 0.167 & 0.039 & 0.086 & 0.121 & 0.034 \\
\hline 166 & 0.034 & - & 0.015 & 0.061 & 0.029 & 0.052 & 0.069 & 0.102 \\
\hline 168 & - & - & - & 0.045 & 0.01 & 0.023 & - & 0.023 \\
\hline 170 & - & 0.009 & 0.005 & 0.015 & 0.02 & 0.017 & 0.017 & 0.011 \\
\hline 172 & - & - & - & - & - & - & 0.121 & - \\
\hline 174 & 0.011 & - & 0.005 & - & - & - & - & - \\
\hline 176 & - & 0.009 & 0.005 & 0.015 & - & 0.006 & - & - \\
\hline 180 & - & - & - & - & - & - & 0.034 & 0.011 \\
\hline 196 & - & - & - & - & - & - & 0.017 & 0.057 \\
\hline 198 & - & - & - & - & - & - & 0.034 & 0.045 \\
\hline 202 & - & - & - & - & - & - & - & 0.023 \\
\hline 204 & - & - & - & - & - & - & - & 0.045 \\
\hline 206 & - & - & - & - & - & - & 0.052 & - \\
\hline$H_{\mathrm{e}}$ & 0.68 & 0.68 & 0.68 & 0.82 & 0.83 & 0.83 & 0.92 & 0.94 \\
\hline$f$ & 0.11 & -0.086 & 0.008 & $0.136 * *$ & $0.205^{* * *}$ & $0.192 * * *$ & $0.107 *$ & $0.32 * * *$ \\
\hline$n$ & 14 & 11 & 16 & 13 & 15 & 17 & 16 & 19 \\
\hline \multicolumn{9}{|l|}{ Strutta-58 } \\
\hline 101 & 0.023 & - & 0.01 & 0.03 & - & 0.011 & 0.086 & 0.09 \\
\hline 103 & 0.045 & 0.009 & 0.026 & 0.045 & 0.029 & 0.034 & - & 0.103 \\
\hline 105 & - & - & - & - & - & - & 0.069 & - \\
\hline 107 & - & 0.009 & 0.005 & - & - & - & - & 0.051 \\
\hline 117 & 0.023 & 0.037 & 0.031 & 0.015 & 0.01 & 0.011 & - & 0.051 \\
\hline 119 & - & - & - & - & 0.01 & 0.006 & 0.069 & - \\
\hline 121 & - & - & - & - & 0.01 & 0.006 & 0.052 & 0.077 \\
\hline 123 & - & 0.019 & 0.01 & - & - & - & 0.052 & 0.115 \\
\hline 125 & 0.023 & 0.019 & 0.02 & 0.015 & 0.048 & 0.034 & 0.138 & 0.064 \\
\hline
\end{tabular}


Table 3 Continued

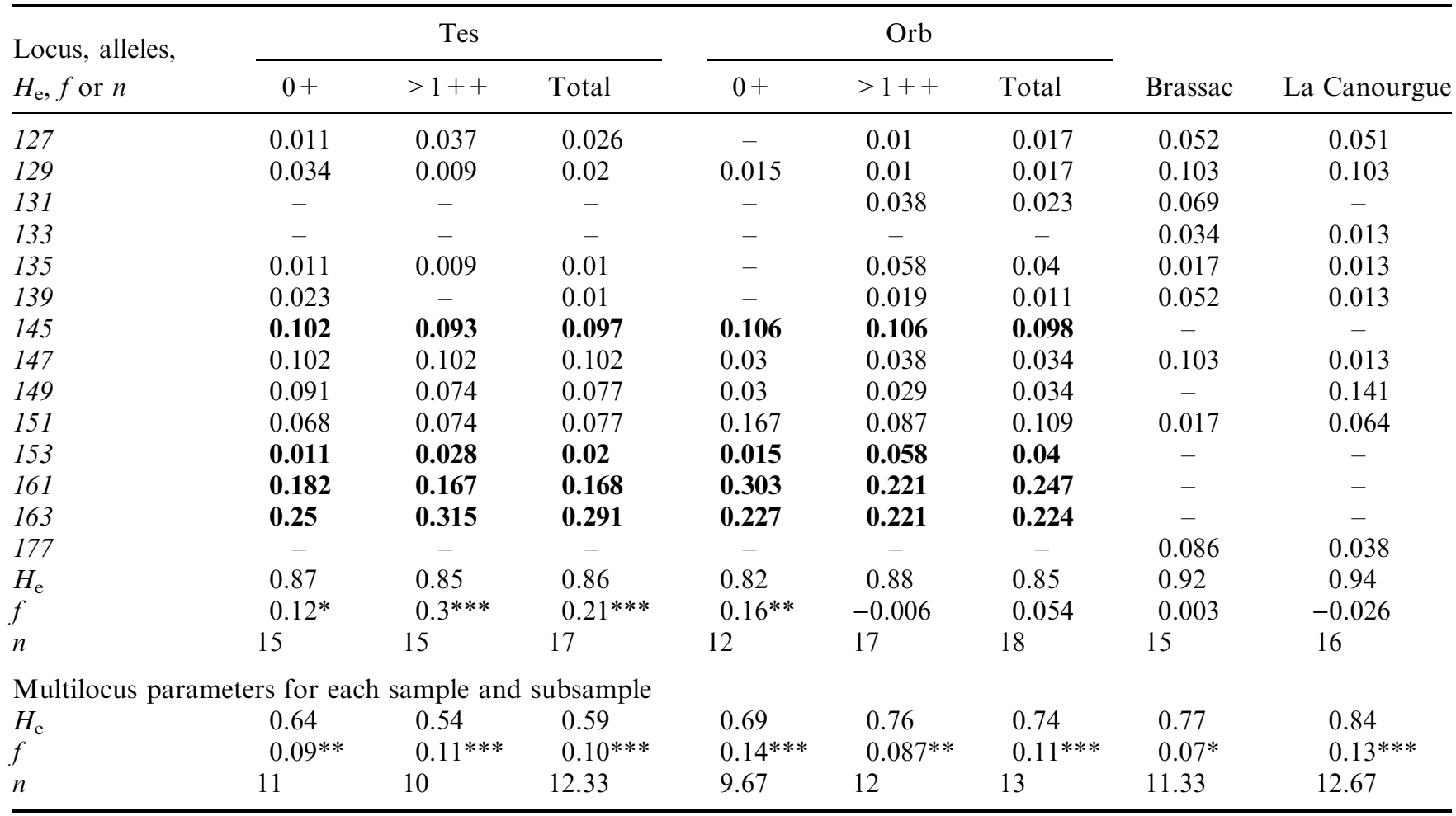

$N$, sample size.

Allelic distributions in bold type indicate the alleles diagnostic of wild populations.

$* P<0.05, * * P<0.01, * * P<0.001$.

The allele types (i) and (ii) cannot be used to estimate introgression. If we consider that introgression is evidenced by the alleles observed in wild and hatchery samples, the introgression index we computed is simply the cumulative frequencies of shared alleles (Table 4). The indices then ranged from 13 to $68 \%$. MST-73 gave exactly the same level of introgression as $T f^{*}$ whereas values for the other two microsatellite loci are higher than those for proteins but close to the mtDNA estimates (Table 4). Nevertheless, the same pattern of variation, that is the frequency of alleles shared with domestic strains is higher in the Orb samples than in the Tes, was observed for Strutta-12 and MST-73, Strutta-58 showing similar values for all samples. We will discuss below the limits of this kind of index and we will question the usefulness of microsatellite loci to answer problems of introgression.

\section{Discussion}

The situation under study is characterized by the human influence on wild Mediterranean trout populations. The ancestral composition of French Mediterranean trout populations is now lost and we are left to

Table 4 Introgression index for protein loci, mtDNA and microsatellite loci for the brown trout samples

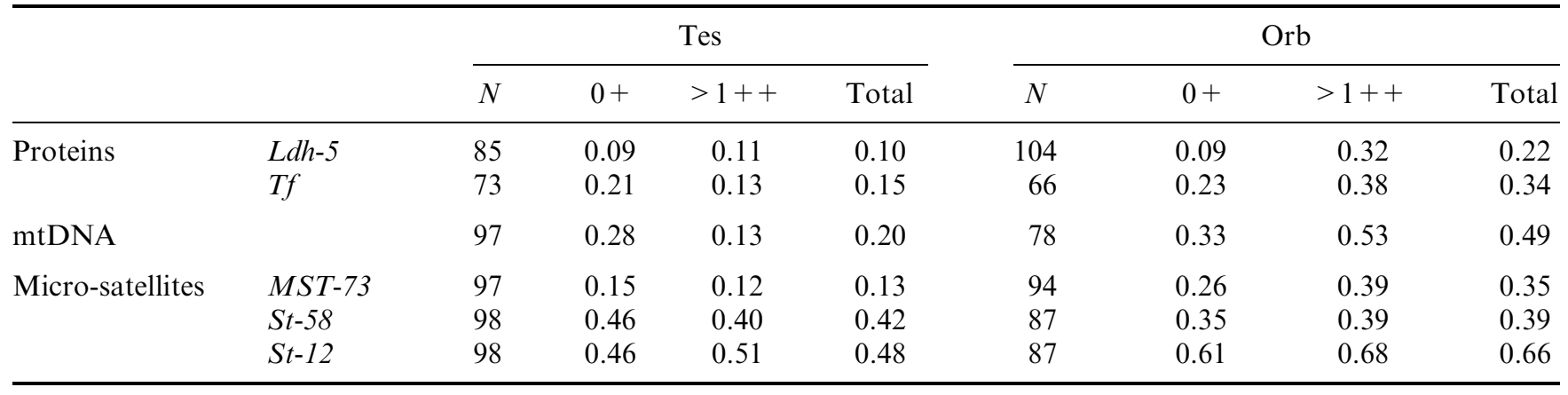


deduce it by subtracting the effects of introgression of domestic genes. Introgressed populations are reproducing populations. Their structure is of interest because they constitute field-wide experiments of interactions between differentiated gene pools a priori adapted to different environmental conditions, an issue which has important bearings in conservation biology. We report here two separate pieces of evidence for which we must find satisfactory explanations. One is the existence of large heterozygote deficiencies. The other is an apparent difference, and a possible decrease, in the level of introgression when stocking has ceased.

\section{Departure from Hardy-Weinberg equilibrium in hatchery and wild populations}

For the hatchery populations, the departure from Hardy-Weinberg expectations shown by both samples could be easily explained by the mixing of different sets of offspring (because of fish farms' practice of introducing progenitors from other hatcheries or from rivers of the Atlantic basin). A previous analysis with microsatellites showed that no deficits were obtained for trout populations from the Moselle River, not disturbed by restocking (Estoup et al., 1998), whereas in the case of our wild restocked populations, we observed deficits of about 10\%. Rico et al. (1997) reviewed the possible causes of excess homozygosity. From their list, we will take three hypotheses to explain the heterozygote deficits observed in the Orb and Tes populations.

(i) Null alleles. Here, heterozygote deficits were high and detected at different microsatellite loci for the two samples (Table 3). The expected allele frequency of the null allele in the Tes River, the Orb River and both hatchery samples was $0.038,0.05,0.0006$ and 0.063 , respectively. Because of these relatively low frequencies, this cause cannot explain all the disequilibria.

(ii) A Wahlund effect either in time (overlapping of genetically differentiated generations) or in space (migration between genetically differentiated populations). In this last case, it would mean that these hypothetical populations show between them $F_{\mathrm{ST}}$ values similar to the $F_{\text {IS }}$ observed when they are mixed $(\approx 10 \%$ whereas the higher $\theta$ value obtained here was only $3 \%$ ). We doubt that such subpopulations can coexist generation after generation in the same relatively small river drainage. Similarly, if an effect were to be sought because of overlapping generations we would still have to explain how these generations could be so different, and also the different age-groups should show much larger genetic differences than we saw.

(iii) Finally, assortative mating or selection against heterozygotes could cause all or a part of these deficits.
Because restocking results in the admixture of differentiated gene pools, one cannot reject a priori the possibility that some assortative mating or differential survival of genotypes plays a part in these heterozygote deficiencies, although we have no direct evidence for this hypothesis.

Actually, we can not conclude unambiguously which cause explains the excess homozygosity observed and no single factor may alone provide a satisfactory explanation.

\section{Putative assessment of introgression with microsatellite data}

The diagnostic power of protein-coding loci and mtDNA haplotypes is relatively well established (Krieg \& Guyomard, 1985; Giuffra et al., 1996) but, for microsatellites, some wild alleles scored as identical to hatchery alleles introduce an uncertainty on the nature of such shared alleles. They may have three origins: (i) convergent mutation; (ii) common ancestral polymorphism; or (iii) introgression. Here, because few alleles are shared with the hatchery samples, the least polymorphic microsatellite locus gives introgression levels similar to those given by protein-coding loci. At the opposite, the most variable ones give higher introgression levels because of numerous alleles shared and at low frequency. The discrepancy between introgression results from markers and from microsatellite loci suggests that estimates of introgression using molecular methods should still be interpreted with caution. But we disagree with the idea that polymorphic microsatellite loci should only be used to analyse population structure or geographical differentiation, and we suggest that most of the variability observed in these disturbed populations has a foreign origin.

No undisturbed Mediterranean subpopulations still exist in this drainage and we could not compare our introgressed samples with a pure reference to identify diagnostic microsatellite alleles. However, we decided not to include pure reference samples from a distinct river drainage in this study because (i) owing to the high rate of evolution of such markers, large differences between basins are probable in the microsatellite alleles' composition in the wild (e.g. Brunner et al., 1998) and (ii) even if allozymes showed that loci were fixed for wild alleles, we could not be sure that no ancient unknown introgression had occurred and that no foreign microsatellite alleles had been fixed following founder effects or bottleneck events (Poteaux et al. unpubl. data). Nevertheless, to establish comparisons, we used an index which gives a maximum introgression by addition of all shared alleles among domestic and wild populations, therefore assuming that shared alleles are too numerous to be explained by ancestral polymorphism or homoplasy. 
The low polymorphism of allozymes (Krieg \& Guyomard, 1985; Moran et al., 1993; Poteaux \& Berrebi, 1997) and mtDNA (Apostolidis et al., 1996) suggests that these riverine systems probably host trout populations of small effective sizes. Indeed, for the Orb River drainage, direct population estimates based on individual density per hectare and on spawning grounds inventories during several winters in both rivers (Beaudou, 1993) have yielded values on the order of 200-250 progenitors. In our case, with overlapping generations, we can then be confident that the effective population size $\left(N_{e}\right)$ is much smaller than the observed number of spawning fishes. Hence, if $N_{e}$ is small, we expect a small number of alleles at mutation/drift equilibrium, and shared alleles should then more likely reflect introgression rather than convergence or parallelism. If we compute the heterozygosity expected at mutation/drift equilibrium with the infinite allele model (IAM; Kimura \& Crow, 1964), this quantity $H_{\mathrm{e}} \approx 0.6-0.7$ is obtained with a mutation rate higher than $10^{-3}$ or for $N_{\mathrm{e}}$ values much larger than expected for this kind of river. However, a mutation rate higher than $10^{-3}$ is not possible because no mutation event was detected by the analysis of 334 backcross progeny at these loci (Poteaux et al. submitted). A good part of the observed variability is therefore probably of foreign origin. All this suggests that introgression is a powerful means of increasing the levels of heterozygosity in rivers by introducing novel alleles into trout populations. Our index of 'maximum introgression' thus seems reliable enough to monitor fluctuations of introgression.

\section{Differentiation between wild populations}

Microsatellite markers gave results consistent with proteins and mtDNA data, in that the restocked Orb population was more polymorphic than the Tes population and, using the 'maximum introgression' index, appeared to have a higher frequency of 'domesticated genes'. It is noteworthy that a significant difference of microsatellite allele frequencies, especially for alleles of domesticated origin, can be detected for all loci between the two rivers. Small et al. (1998) observed a significant structure between coho salmon populations from the upper and lower part of the Fraser River drainage. They supposed that the regional structure observed might be maintained by adaptive differences between the two groups. At the lower scale of our study, there is no obstacle between the upper part of the Tes River and the Orb River, downstream. Because migrations were effective at some periods, this opens the question of the nonhomogenization of both gene pools. Tes samples (both age groups) still showed some alleles originating from hatchery stocks, but at lower frequency than in the Orb. The complete elimination of hatchery alleles in the undisturbed river, if it is to occur, is very unlikely to be observed in our case because restocking ceased only 6 years before the study, that is only two trout generations, and because Orb progenitors can move upstream for mating. Nevertheless, our results mean that 6 years without restocking were sufficient to create, or enhance if it already existed, a significant difference between the two rivers.

\section{Conclusion}

Microsatellite markers used here reveal a slight genetic differentiation between tributaries within the same basin. Our study was a first attempt to evaluate with microsatellite loci the impact of hatchery trout on wild populations. Although the introgression of hatchery genes in the wild populations is likely to be overestimated, a better method cannot be proposed because of the lack of pure reference samples. Nevertheless, our relatively simple approach gives coherent results. This opens the way to the study of the fate of introduced genes with a genome coverage larger than previously attainable by proteins and mtDNA.

\section{Acknowledgements}

We wish to thank J. Dallas, E. Desmarais and F.J. Garcia de Leon for technical help, S. Baird, J. Dallas, B. Dod, D. Hedgecock and F. Rousset for useful comments on the manuscript. This work was supported by the 93-179 grant from the Conseil Supérieur de la Pêche, the Fédération de Pêche de l'Hérault and EC contract EV5VCT920097. C.P. was supported by a fellowship from the French Ministère de l'Education et de la Recherche.

\section{References}

APOSTOLIDIS, A., KARAKOUSIS, Y. AND TRIANTAPHYLLIDIS, C. 1996. Genetic divergence and phylogenetic relationships among Salmo trutta L. (brown trout) populations from Greece and other European countries. Heredity, 76, 551-560.

BARBAT-LETERRIER, A., GUYOMARD, R. AND KRIEG, F. 1989. Introgression between introduced domesticated strains and Mediterranean native populations of brown trout (Salmo trutta L.). Aquat. Living Resour., 2, 215-223.

BEAUDOU, D. 1993. Impact des déversements de truites domestiques dans les populations naturelles de truites commune (Salmo trutta). Etude dynamique et génétique. Cas du bassin de l'Orb (Hérault). PhD Thesis, University of Montpellier II.

BELKHIR, K., BORSA, P., GOUDET, J., CHIKHI, L. AND BONHOMME, F. 1996-98. GENETIX, Windows ${ }^{T M}$ software for population genetics. Laboratoire Génome et Populations, CNRS UPR 
9060, University of Montpellier II, Montpellier (France); http: //www.univ-montp2.fr/ genetix/genetix.htm.

BERNATCHEZ, L., GUYOMARD, R. AND BONHOMME, F. 1992. DNA sequence variation of the mitochondrial control region among geographically and morphologically remote European brown trout Salmo trutta populations. Mol. Ecol., 1, 161-173.

BROOKFIELD, J. F. Y. 1996. A simple new method for estimating null allele frequency from heterozygote deficiency. Mol. Ecol., 5, 453-455.

BRUNNER, P. C., DOUGLAS, M. R. AND BERNATCHEZ, L. 1998. Microsatellite and mitochondrial DNA assessment of population structure and stocking effects in Arctic charr Salvelinus alpinus (Teleostei: Salmonidae) from central Alpine lakes. Mol. Ecol., 7, 209-223.

CROW, J. F. AND KIMURA, M. 1970. An Introduction to Population Genetics Theory. Harper and Row, New York.

ESTOUP, A., PRESA, P., KRIEG, F., VAIMANT, D. AND GUYOMARD, R. 1993. $(\mathrm{CT})_{\mathrm{n}}$ and $(\mathrm{GT})_{\mathrm{n}}$ microsatellites: a new class of genetic markers for Salmo trutta L. (brown trout). Heredity, 71, 488-496.

ESTOUP, A., PRESA, P., KRIEG, F., VAIMANT, D. AND GUYOMARD, R. 1998. Comparative analysis of microsatellite and allozyme markers: a case study investigating microgeographic differentiation in brown trout (Salmo trutta). Mol. Ecol., 7, 339353.

Garcia de leon, F., Dallas, J., Chatain, B., CANONne, M., VERSINI, J. J. AND BONHOMME, F. 1995. Development and use of microsatellite markers in sea bass, Dicentrarchus labrax (Linnaeus, 1758) [Perciformes: Serranidae]. Mol. Mar. Biol. Biotech., 4, 62-68.

GARCIA-MARIN, J. L., JORDE, P.E., RYMAN, N., UTTER, F. AND PLA, C. 1991. Management implications of genetic differentiation between native and hatchery populations of brown trout (Salmo trutta) in Spain. Aquaculture, 95, 235-249.

GIUFFRA, E., GUYOMARD, R. AND FORNERIS, G. 1996. Phylogenetic relationships and introgression patterns between incipient parapatric species of Italian brown trout (Salmo trutta L. complex). Mol. Ecol., 5, 207-220.

GUYOMARD, R. 1989. Diversité génétique de la truite commune. Bull. Fr. Pêche Pisc., 314, 118-135.

HINDAR, K., RYMAN, N. AND UTTER, F. 1991. Genetic effects of cultured fish on natural fish populations. Can. J. Fish. Aquat. Sci., 48, 945-957.

KIMURA, M. AND CROW, J. F. 1964. The number of alleles that can be maintained in a finite population. Genetics, 49, 725-738.

KRIEG, F. AND GUYOMARD, R. 1985. Population genetics of French brown trout (Salmo trutta L.): large geographical differentiation of wild populations and high similarity of domesticated stocks. Génét. Sél. Évol., 17, 225-242.
MORAN, P., GARCIA-VASQUEZ, E., PENDAS, A. M., IZQUIERDO, J. I. AND MARTIN VENTURA, J. A. 1993. Status of genetic conservation in salmonid populations from Asturian rivers (North of Spain). In: Cloud, J. G. and Thorgaard, G. H. (eds) Genetic Conservation of Salmonid Fishes, NATO ASI Series: Life Sciences 248. pp. 213-218. Plenum Press, New York.

NEI, M. 1978. Estimation of average heterozygosity and genetic distance from a small number of individuals. Genetics, $\mathbf{8 9}$, 583-590.

POTEAUX, C. AND BERREBI, P. 1997. Genome integrity and trout restocking on the Mediterranean versant. Bull. Fr. Pêche Pisc., 344/345, 309-322.

POTEAUX, C., BONHOMME, F. AND BERREBI, P. 1998a. Differences between nuclear and mitochondrial introgressions of brown trout populations from a restocked main river and its unrestocked tributary. Biol. J. Linn. Soc., 63, 379-392.

POTEAUX, C., BEAUdOU, D. AND BERREBI, P. 1998b. Temporal variations of genetic introgression in stocked brown trout (Salmo trutta L.) populations. J. Fish Biol., 53, 701-713.

PRESA, P. 1995. Déterminisme et polymorphisme génétiques des séquences microsatellites de Salmo trutta et d'autres Salmonidés. Comparaison avec le polymorphisme des locus enzymatiques. PhD Thesis, University of Paris XI, Orsay.

PRESA, P., KRIEG, F., ESTOUP, A. AND GUYOMARD, R. 1994. Diversité et gestion génétique de la truite commune: apport de l'étude du polymorphisme des locus protéiques et microsatellites. Génét. Sél. Evol., 26 (Suppl. 1), 183s-202s.

RICO, C., RICO, I. AND HEWITT, G. M. 1997. Stock composition in North Atlantic populations of whiting using microsatellite markers. J. Fish Biol., 51, 462-475.

RICO, C., ZADWORNY, D., KUHNLEIN, U. AND FITZGERALD, G. J. 1993. Characterization of hypervariable microsatellite loci in the threespine stickleback Gasterosteus aculeatus. Mol. Ecol., 2, 271-272.

SAMBROOK, J., FRITSCH, E. F. AND MANIATIS, T. 1989. Molecular Cloning. A Laboratory Manual. Cold Spring Harbor Laboratory Press, New York.

SMALL, M. P., BEACHAM, T. D., WITHLER, R. E., NELSON AND R. J. 1998. Discriminating coho salmon (Oncorhynchus kisutch) populations within the Fraser River, British Columbia, using microsatellite DNA markers. Mol. Ecol., 7, 141-155.

STOCS, 1981. Stock Concept International Symposium. Can. J. Fish. Aquat. Sci., 38, 1457-1921.

WEIR, B. S. AND COCKERHAM, C. C. 1984 . Estimating $F$-statistics for the analysis of population structure. Evolution, 38, 1358-1370.

Wright, s. 1951. The genetical structure of populations. Ann. Eugen., 15, 323-354. 